\title{
Review
}

\section{Viral Dramaturgies: HIV and AIDS in performance in the Twenty-First Century}

\section{Edited by Alyson Campbell and Dirk Gindt}

Cham: Palgrave Macmillan, 2018, 417 p.

\section{CAOIMHE MADER MCGUINNESS, Kingston University London}

The Netflix revival in 2019 of Tales of the City, the television adaptation of Armistead Maupin's popular series of LGBT novels of the same name, features a key moment of queer intergenerational tension surrounding the question of HIV. In this scene, Ben, a young black gay man attends a dinner party organized by acquaintances of his significantly older HIV positive boyfriend and gets into trouble for berating one of the other guests, an older white man, for using an offensive term. As Ben uses the word "privilege" to describe the other guest's dismissive attitude, the latter launches into a tirade, affirming angrily: "Any privilege [you enjoy now] was won. [...] At your age I wasn't going to dinner parties I was going to funerals." This particular exchange might be seen to encapsulate a common example of how Queer Western intergenerational tensions have come to be represented in arts and culture, presuming HIV as a phenomenon located in the past, which mostly affected white gay men, and not fully comprehensible to an empowered younger generation of queer people free from the fear of AIDS related death - a misconception about the realities of HIV that Alyson Campbell and Dirk Gindt's welcome edited collection hopes to correct. 
Indeed, one of Viral Dramaturgies' stated intents is to move beyond the double bind of cultural amnesia and nostalgia that surrounds the ways HIV and AIDS are discussed today. In the introduction to the volume, Campbell and Gindt highlight how contemporary memorialization has tended to present the pandemic as being "over", thus retrospectively valorizing the work and experiences of mainly white Western gay male artists (21). They state: "Nostalgia also feeds into the cultural commodification of HIV and AIDS, which reproduces and simplifies narratives for mass consumption while simultaneously erasing both the past experiences of marginalised constituencies such as sex workers, trans people and injecting drug users and the experience of people living with HIV today" (24-25). Both editors thus position their book as a refutation of this nostalgic trap which assumes that "HIV and AIDS in performance, along with its scholarship, is done and dusted," hoping instead that their collection will "demonstrate that this is still a burgeoning, ever shifting field [...]" (5).

In order to fulfil this promise, this edited volume offers a substantial number of interventions as diverse in themes as they are in scope and authorship. The Introduction flags a series of contemporary concerns for HIV and AIDS research and performance. These range from the ongoing inequalities between North and South, the partial availability of "blue" (Pre-Exposure Prophylaxis - PreP), the criminalization of HIV and AIDS, the continued stigma suffered by those who have contracted the virus and, importantly, the continued invisibility of many populations in representations of the illness. It is therefore fitting that one of the first chapters in the book by sex work activists Elena Jeffreys and Janelle Fawkes focuses on how sex workers have used performance to emphasize the vital yet obscured role they play in HIV prevention, and stress that "decriminalisation of sex work [is] an important component of any response to HIV" (71). As a community at the frontline of HIV advocacy and public health discourses, this chapter highlights the creativity that sex workers from Australia to Cambodia have deployed in order to stage themselves not as recipients but as agents in the global fight against the pandemic - for example through performing playful arrests at the World Aids conferences or developing plays charting their activist successes as a tool for education.

The activist function of performance practice is a thread that runs throughout the book, highlighting the role performance can play in diverse contexts as an advocacy tool or a means for self-expression. Jacqueline Kauli discusses the process of Awareness Community Theatre in Papua New-Guinea, where the company worked with indigenous populations to offer HIV education and prevention in a society in which "individual autonomy held little traction in local communities" and "development of narratives for performances needed to be nuanced if it was to make a difference at all" (280). Elsewhere, Katharine Low, Matilda Mudyavanhu and Shema Tariq narrate how engaging in applied theatre projects with African migrant women in London was a means to address the epistemic violence suffered by these women due to their complete erasure within HIV policy discourses and artistic representation. Meanwhile, Ola Johansson draws from Carl Bogg's conceptualization of prefigurative politics, a form of political organizing which seeks to embody the radical democracy it also struggles for, to link the practices 
of ACT UP with HIV activist practices in Tanzania and South Africa. Whilst each intervention is localized and specific, the inclusion of a broad range of discussions of community art projects demonstrates the potential efficacies of theatre and performance challenging stigma.

A further key theme of the collection is the relationship between memory and memorialization, mostly as this pertains to Western queer contexts but equally diverse in objects of study. Dirk Gindt offers a thoughtful yet critical assessment of the success of the recent Swedish hit television show Don't Ever Wipe Tears Without Gloves. He considers the public confessions of crying provoked by the show on Twitter, arguing that the melodramatic form of the show entrenches a vision of HIV as having primarily affected white gay men in the 1980s and 1990s over other groups such as drug users and sex workers. Gindt understands this seemingly shared collective affect as both a display of neoliberalized sentimentality, with little critical or material significance on the realities of HIV. Yet he also attempts to recognize the historical value of the experiences represented that until the show's airing "had rarely been told in Sweden" (250), self-avowedly avoiding the trap of what Eve Sedgwick has called a "paranoid reading." Equally thoughtful is Peter Dickinson's exploration of "temporal transitivity" within Drag performances in Vancouver and Montreal. He focuses on work which not only addresses intergenerational relationships and historical queer sites of community organization and HIV activism, but has also encouraged the reinvestment by LGBT and Drag communities of these historical sites for contemporary shows and club nights. Framing his arguments via Elizabeth Freeman and Judith Butler's work, he concludes that this work, just like the global political movement that emerged in response to HIV, demonstrates that "distance and absence are not impediments to coming together" and that "gesturing back to where we have come from, pointing the way forward, and in that nexus [reminds] us what we still need to be angry about" (129).

This is also something that might apply to Viral Dramaturgies as a whole; while the scope of this review cannot accommodate many of the other incisive contributions of the collection - including an interview with Sarah Shulman, accounts of theatrical representations of AIDS in China or discussions of pedagogical practices emerging from making work about HIV with groups of students - a definite strength of Campbell and Gindt's intervention is how it unsettles the nature of mainstream representation of AIDS with which I opened this review. While clearly acknowledging the intertwined and difficult histories of HIV in Western queer communities, the editorial choices also emphasize these discussions as necessarily in conversation with the present. This remind readers not only what to be angry about, but also crucially, what is at stake when misplaced nostalgia stands in the way of comprehensively showing the multitude of people affected by the pandemic, and their multitudinal ways of representing their lives, and crucially, of resisting. 